\title{
IGUALDADE DE TODOS PERANTE A LEI
} EQUALITY OF ALL BEFORE THE LAW

\author{
Francisco Campos
}

\section{SUMARIO}

Primazia da cláusula de igualdade perante a lei - Latitude do princípio - Sua obrigatoriedade para o legislador - Subordinação do princípio de legalidade ao de constitucionalidade - A tese contrária de Anschütz; refutação de Stier-Somlo, Kaufmann, Triepel, W. Jellinek e Schimitt Inconsistência dos argumentos de Anschütz - Aplicação do princípio da igualdade dos direitos, coisas e fatos - Conceito de lei como disposição de caráter geral - O "Estado de Direito" e o conceito de lei - Conceito formal de lei - Conceito de lei na Constituição brasileira de 1946 - A impossibilidade de discriminações arbitrárias, garantia máxima da declaração constitucional de direitos.

${ }^{*}$ Omissis.

A Constituição, art. 141, $\S 1^{\circ}$, dispõe:

"Todos são iguais perante a lei".

Primazia da cláusula de igualdade perante a lei

$\left.1^{\circ}\right)$ A cláusula relativa à igualdade diante da lei vem em primeiro lugar, na lista dos direitos e garantias que a Constituição assegura aos brasileiros e aos estrangeiros residentes no país. Não foi por acaso ou arbitràriamente que o legislador constituinte iniciou com o direito à igualdade a enumeração dos

* Excerto de um parecer, no qual o autor sustenta a incompatibilidade dos decretos-leis ns. 6.425, de 14-4-1944, e 7.669, de 22-6-1945, com a Constituição de 1946. 
direitos individuais. Dando-lhes o primeiro lugar na enumeração, quis significar expressivamente, embora de maneira tácita, que o princípio de igualdade rege todos os direitos em seguida a êle enumerados. E' como se o art. 141 da Constituição estivesse assim redigido: "A Constituição assegura com igualdade os direitos concernentes à vida, à liberdade, à segurança individual e à propriedade, nos termos seguintes"...

Quando, efetivamente, a Constituição assegura a liberdade, a propriedade e os demais direitos individuais, ela os assegura não só indiscriminadamente ou a todos, mas a todos na mesma medida e mediante as mesmas condições. Enunciando o direito à igualdade em primeiro lugar, o seu propósito foi, precisamente, o de significar a sua intenção de proscrever, evitar ou proibir que, em relação a cada indivíduo, pudesse variar o tratamento quanto aos demais direitos que ela assegura e garante. $O$ direito à igualdade rege os demais direitos individuais, devendo ser subtendida, em cada um dos parágrafos seguintes ao em que êle vem enunciado, a cláusula relativa à igualdade diante da lei.

No grande tratado, em três volumes, publicado em 1929 e em que colaboraram os maiores juristas da Alemanha, todo êle dedicado ao comentário da segunda parte da Constituição de Weimar, na qual eram declarados os direitos fundamentais, Stier-Somlo, professor de direito público na Universidade de Colônia, a quem coube comentar o art. 109, em que se enuncia, iniciando a lista dos direitos individuais assegurados naquela Constituição, o princípio de igualdade, observa que, da primazia assim conferida à igualdade diante da lei (Gleichheit vor dem Gesete), resulta o inequívoco propósito do legislador constituinte de que os demais direitos em seguida enumerados ficassem sob a imediata regência daquele princípio: "Schon damit ist seine unübertroffene Bedeutung im Rahmen dieses Hauptteils betont, ihm die Rolle des Auftakts nicht ohne besondere Wirking zugewiesen. Er beherrscht alle nachfolgende Grundrechte, mindestens die die Einzelperson angenhenden, in dem Sinne, dass die in ihm niedergelegten Grundanschauung auch für die nachfolgende massgeblich sind, insbesondere durch sie nicht eingeengt werden dürfen. Er gilt, ohne dass ihm die Vorbehalte der Individualrechte (arts. 111, 112, 114, 117, 118) Abbruch tun können" (Stier-Somlo), "Gleichheit vor dem Gesetz". Em "Grundrechte und Grundpflichten der Reichsverfassung", herausgegeben von Hans Karl Nipperdey, vol. I, pág. 158).*

\footnotetext{
*As citações em alemão foram revistas por Fernando Leal; em inglês, por Felipe Assensi e Tatiana Mesquita; em francês, por Ronald Polito.
} 
Ou, em português: "Com isto" (isto é, com a sua colocação em primeiro lugar) "se quis acentuar a significação suprema que lhe cabe no quadro dessa parte principal" (da Constituição) "e a êle fica conferido, de maneira particularmente efetiva, o papel de compassar os direitos fundamentais subseqüentemente enumerados. Ele rege os direitos fundamentais subseqüentes, pelo menos os relativos aos indivíduos, no sentido de que lhes serve de regra ou de medida, não podendo, por parte dêles, sofrer qualquer restrição, assim como qualquer restrição àqueles direitos (arts. 111, 112, 114, 117, 118) não pode estender-se a êle".

Nas declarações de direitos - que constituem parte obrigatória de quase tôdas as Constituições democráticas do mundo - em relação a vários dêles a Constituição, depois de os declarar, em têrmos absolutos faz a reserva de que, entretanto, a lei poderá criar-lhes restrições. Assim, na Constituição de Weimar, o art. 111, depois de declarar o direito para todo alemão de circular livremente em todo o território nacional, de se fixar em qualquer localidade, etc., acrescenta, logo em seguida, que a êsse direito sòmente uma lei federal poderá estabelecer limitações; da mesma maneira, quanto à liberdade de emigração (art. 112), à liberdade pessoal (art.114), ao sigilo das cartas e ao segredo postal, telegráfico e telefônico (art. 117), à liberdade de manifestação do pensamento (artigo 118).

Na Constituição brasileira de 1946, igualmente, há vários direitos ali assegurados, aos quais, entretanto, se acrescentam, logo após o enunciado geral, as restrições ou limitações que a lei poderá criar-lhes. E' o caso dos $\S \S 5^{\circ}, 7^{\circ}$, $8^{\circ}, 11,13,15,16$ e 20.

Em relação à igualdade, porém, a Constituição não admite, em caso algum, qualquer derrogação legal ao princípio por ela estabelecido. Êsse princípio ela o enuncia em têrmos absolutos ou plenários, com isto manifestando a intenção de que êle se torne efetivo em tôda a latitude do seu sentido em qualquer circunstância, seja qual fôr a situação ou a condição da pessoa, a natureza da coisa, a espécie da relação, o estado de fato que a lei pretenda reger. Não haverá condições à igualdade perante a lei. A lei será igual para todos e a todos se aplicará com igualdade. E' um direito incondicional ou absoluto. Não tolera limitações, não admite exceção, seja qual fôr o motivo invocado: lei alguma, nenhum poder, nenhuma autoridade poderá, direta ou indiretamente, de modo manifesto ou sub-reptício, mediante ação ou omissão, derrogar o princípio de igualdade. 


\section{Latitude do princípio}

$\left.2^{\underline{9}}\right)$ Quais a extensão e a natureza do direito à igualdade perante a lei? Nas primeiras declarações de direitos, que se seguiram imediatamente às revoluções que, no fim do século XVIII, puseram fim ao antigo regime, abolindo as classes, os privilégios de nascimento, as regalias de tôda ordem, que resultavam em profundas diferenciações sociais, poder-se-ia atribuir ao princípio de igualdade uma significação estrita, no sentido de que a sua finalidade constituía tão sòmente em suprimir e impedir que renascesse a estrutura social que a revolução acabava de desmontar ou destruir.

$\mathrm{E}^{\prime}$, por exemplo, o que poderia resultar dos têrmos da declaração dos direitos do homem de 1789:

"Les hommes naissent et demeurent libres et égaux en droits. Les distinctions sóciales ne peuvent être fondées que sur l'utilité commune".

Embora já fôsse corrente na filosofia social e política do século XVIII, e constituísse um dos temas da propaganda revolucionária, a idéia de que a igualdade entre os homens devia ser completa e radical, o certo é que a declaração constitucional da igualdade tinha como foco particular de incidência o regime ou a estrutura social que vinha de ser abolida. A acentuação tônica do princípio de igualdade teria de recair precisamente sôbre o seu conteúdo negativo. Êle era, então, um conceito polêmico e, como é próprio do conceito polêmico, a sua significação ou o seu conteúdo se define melhor de modo negativo do que positivamente, mais por oposição ou negação concreta do que de maneira geral ou abstrata.

Nas constituições modernas, entretanto, particularmente nos países em que não chegaram a vingar as diferenciações sociais fundadas no sangue, na tradição e na fortuna, e em que, portanto, não havia que abolir uma ordem social fundada sôbre a desigualdade, o princípio de igualdade perante a lei deixa de ser um conceito polêmico - ou cujo conteúdo e significação se definem de modo concreto, por antítese com o estado de coisas imediatamente anterior, ou com uma determinada situação histórica, cuja restauração se teme, dado o fato de ainda ser recente a sua abolição e persistirem sinais da sua tendência a perdurar - para ser um conceito sem foco definido de incidência, ou cujo conteúdo, ao invés de limitado pelo sistema de referências que resulta das circunstâncias, comporta as mais amplas, extensas e variadas conotações.

Nas Constituições a que nos referimos, nenhum motivo existe para atribuir ao princípio de igualdade o sentido parcial, particular ou restrito de simples negação a uma ordem de coisas, que nem sequer chegou a existir. 
O alcance do princípio de igualdade perante a lei há de ser, portanto, interpretado na maior latitude dos seus têrmos, ou, como envolvendo não só a hipótese de que, embora não havendo existido, venha, entretanto, a se criar no país o regime de classes, como tôda e qualquer situação, a que, embora casualmente ou episòdicamente, sem caráter sistemático, ou de modo puramente singular, se deixe de aplicar o critério ou medida geral prevista para casos ou situações da mesma espécie, e se lhes aplique critério ou medida de exceção. O princípio não tem, portanto, como foco de incidência um ponto preciso e definido. Êle se difunde por todo o tecido das relações humanas que possam constituir objeto de regulamentação jurídica ou sejam suscetíveis de configurar-se em conteúdo de um ato ou de um comando da autoridade pública. Não é princípio adstrito a um aspecto ou a uma forma de organização social; é um postulado de ordem geral, destinado a reger o comércio jurídico em tôdas as modalidades, de modo a assegurar, particularmente sob as constituições liberais e democráticas, o regime da concorrência, que é a categoria sob a qual elas concebem não sòmente a ordem social, como a ordem política, a ordem econômica e a ordem jurídica. O princípio de igualdade tem por principal função proteger e garantir a livre concorrência entre os homens, seja quando a sua atividade tem por objeto o poder, seja quando o polo do seu interêsse são os bens materiais ou imateriais, cujo gôzo exclusivo lhes é assegurado pelo direito de propriedade. O regime liberal e democrático postula a concorrência não apenas como categoria histórica, mas como a categoria ideal da convivência humana. Ora, a concorrência pressupõe, como condição essencial, necessária ou imprescindível, que o Estado não favoreça a qualquer dos concorrentes, devendo, ao contrário, assegurar a todos um tratamento absolutamente igual, a nenhum dêles podendo atribuir prioridade ou privilégio, que possa colocá-lo em situação especialmente vantajosa em relação aos demais. Esta, no mundo moderno, a significação do princípio da igualdade perante a lei. Por êle, todos ficarão certos de que na concorrência, tomada esta expressão no seu sentido mais amplo, o Estado mantem-se neutro ou não procurará intervir senão para manter entre os concorrentes as liberdades ou as vantagens a que cada um dêles já tinha direito ou que venha a adquirir, mediante os processos normais da concorrência. O princípio de igualdade tem hoje, como se vê, um campo mais vasto de aplicação do que nos tempos que se seguiram imediatamente às suas primeiras declarações. Não só, porém, um campo mais vasto de aplicação, como, igualmente, uma tonalidade diversa da do primitivo metal, em que foi, há mais de um século, esculpido pela primeira vez o seu enunciado. Se, nas Constituições surgidas 
das grandes vagas revolucionárias que começaram, no fim do século XVIII, a varrer as instituições do antigo regime, o princípio de igualdade tinha por objeto principal a negação concreta de um passado recente, o princípio de igualdade, nas Constituições modernas, não se define por oposição a uma ordem social concreta, mas, precisamente, pela afirmação de uma determinada ordem, que já existia antes de existirem aquelas Constituições, e que estas, por lhe atribuírem um valor incondicional, pretendem manter, conservar e assegurar incondicionalmente. A ordem, que tem como postulado fundamental o princípio de igualdade declarado nas modernas Constituições liberais, ao invés de se haver originado de revoluções sociais ou políticas, originou-se, precisamente, da grande revolução industrial e técnica, que teve a sua fase decisiva no princípio do século XIX, e cujo resultado foi a instauração da ordem econômica ainda vigente no mundo ocidental. Essa ordem econômica tem por princípio regulador ou por categoria ética e jurídica fundamental a concorrência, ou, de modo mais preciso, a livre concorrência. Em tal regime, como é intuitivo, a igualdade de oportunidades constitui o postulado fundamental. Não poderá haver regime de livre concorrência se o Estado se reserva o direito de intervir na luta, não com o fim de assegurar a observância das regras do jôgo, mas para conferir a um dos contendores vantagens que, ao mesmo tempo, deixa de tornar extensivas a todos êles, ou criar a um restrições ou embaraços que não se tornem simultâneamente gerais ou comuns a todos.

A igualdade perante a lei tem, assim, hoje em dia, como domínio eletivo de aplicação o campo das atividades econômicas. E' claro que não se restringe exclusivamente a êle. Nos outros domínios, porém, perdeu o interêsse que constituiu a principal razão que determinou o seu enunciado nas primeiras Constituições democráticas. Não existe hoje, com efeito, ainda que remoto, o perigo de que venha a restabelecer-se uma ordem social fundada sôbre discriminação de classes sociais. O motivo que inspira a declaração, nas Constituições modernas, do direito à igualdade perante a lei é de outra ordem. Êle consiste na convicção de que um determinado regime econômico, precisamente o de que a livre concorrência constituiu a categoria lógica, ética e jurídica, não poderá subsistir a não ser se ao Estado se impõe o dever de não alterar, em caso algum, as condições da concorrência, a não ser que tais alterações sejam gerais ou se apliquem indiscriminadamente a todos os concorrentes. Do princípio da igualdade resulta, pois, um conceito particular do Estado e, assim, como veremos mais adiante, um conceito particular de lei. 


\section{Sua obrigatoriedade para o legislador}

$3^{\text {o) }}$ Definidas a extensão e a natureza do princípio da igualdade perante a lei, surge a questão de se saber qual o destinatário do mandamento constitucional que tem por conteúdo aquêle princípio. Dirige-se tão sòmente às autoridades incumbidas de aplicar a lei - à Adminstração e à Justiça ou é, ao contrário, norma obrigatória para todos os órgãos que têm a investidura de formular, em qualquer domínio, a vontade ou a decisão do Estado, e, por conseguinte, uma norma especialmente endereçada ao legislador, que é, dentre êles, o principal? Se o princípio deve reger apenas a aplicação da lei, é claro que ao legislador ficaria devassada a imensidade de um arbítrio sem fronteiras, podendo alterar, à sua discrição, por via de medidas concretas ou individuais, as condições da concorrência, de maneira a favorecer, na corrida, a um dos concorrentes, ou a um grupo de concorrentes, em detrimento dos demais. O que garante, efetivamente, a concorrência não é tão só o princípio da legalidade, entendido como a exigência de que os atos da justiça e da administração possam ser referidos ou imputados à lei. Desde que ficasse assegurada ao legislador a faculdade de alterar a posição de neutralidade do Estado em face dos concorrentes, tomando o partido de uns contra outros, a ordem da concorrência não poderia ter a posição central e dominante que lhe cabe, incontestavelmente, no ciclo histórico que se abriu com a revolução industrial do século passado e que ainda não se pode dar como encerrado no mundo ocidental. O caráter de norma obrigatória para o legislador, para êle em primeiro lugar e para êle especialmente, resulta da natureza e da extensão do princípio de igualdade perante a lei. Seria, de outra maneira, um princípio supérfluo ou destituído de qualquer significação. As autoridades incumbidas de aplicar a lei estão, necessàriamente, adstritas a aplicá-la tal como é a lei, ou de aplicá-la de acôrdo com os seus têrmos. De duas uma, portanto. Ou a lei dispõe de maneira geral e com igualdade para todos os casos que ela regula, e o executor ou aplicador da lei, que está adstrito a aplicá-la com fidelidade, aplicando-a a todos os casos com igualdade, está obedecendo à lei que êle aplica e não ao princípio da igualdade, ou a lei trata desigualmente pessoas, coisas ou fatos, que deveriam ser tratados com igualdade, e, neste caso, ou o aplicador da lei desobedeceria a esta, para obedecer ao princípio de igualdade, e, assim, não estaria aplicando a lei, ou, para cumprir a lei, tal como nela se contém, teria, necessàriamente, ou por dever de ofício, de violar o princípio de igualdade. Em nenhuma das hipóteses, como se vê, haveria 
oportunidade para aplicar a lei de acôrdo com outro princípio que não fôsse o por ela mesma adotado.

Não tem nenhum sentido, portanto, a afirmação de que o princípio de igualdade se destina tão sòmente a reger a aplicação da lei, não se entendendo com o legislador o mandamento de observar, êle mesmo, ao elaborar e editar a lei, o princípio de que aos iguais deverá dispensar igual tratamento (StierSomlo, "Gleichheit vor dem Gesetz", em "Grundrechte und Grundpflichten der Reichsverfassung", vol. I, pág. 181; Triepel, "Die Gleichheit vor dem Gesetz im Sinne des Art. 109 der Reichsverfassung", em "Veröffentlichungen der Vereiningung der Deutschen Staatsrechtslehrer", Heft 3, 1927, pág. 48; Erich Kaufmann, em "Veröffentlinchungen der Vereinigung der Deutschen Staatsrechtslehrer", Heft, 3, 1927, pág. 6).

Aliás, nos sistemas constitucionais do tipo do nosso não cabe qualquer dúvida quanto ao principal destinatário do princípio constitucional de igualdade perante a lei. $\mathrm{O}$ mandamento da Constituição se dirige particularmente ao legislador e, efetivamente, sòmente êle poderá ser o destinatário útil de tal mandamento. $\mathrm{O}$ executor da lei já está, necessàriamente obrigado a aplicá-la de acôrdo com os critérios constantes da própria lei. Se esta, para valer, está adscrita a se conformar ao princípio de igualdade, o critério da igualdade resultará obrigatório para o executor da lei, pelo simples fato de que a lei o obriga a executá-la com fidelidade ou respeito aos critérios por ela mesma estabelecidos.

\section{Subordinação do princípio de legalidade ao de constitucionalidade}

Nos regimes como o nosso, em que o princípio de legalidade é secundário, ou subordinado ao princípio superior, que é o de constitucionalidade, não pode haver dúvida quanto à obrigatoriedade do princípio de igualdade, se prescrito na Constituição, para o legislador, sobretudo para êle, particularmente, especialmente ou com prioridade, para êle. À Constituição não se acham, com efeito, subordinados apenas os órgãos de execução, mas também o órgão central de elaboração da vontade do Estado, o qual é, precisamente, o legislador. Os mandamentos constitucionais obrigam, igualmente, o Poder Legislativo, cujos atos só valerão se puderem ser imputados ao Estado por intermédio da Constituição. Nenhum ato poderá, efetivamente, ser imputado ao Estado, se contravém a uma disposição constitucional. Entre o legislador 
e o Estado está a Constituição e sòmente mediante esta é que se fará àquele a imputação jurídica dos atos das pessoas físicas investidas da função de manifestar a sua vontade. Constitui lugar comum de direito constitucional americano que o Poder Legislativo não pode excetuar-se à observância das normas constitucionais, a elas estando sujeito no mesmo grau e da mesma maneira que os demais departamentos do Govêrno. Seria supérfluo, e mais do que supérfluo, passível de mofa, perder alguém o seu tempo em enfileirar citações de autores americanos e referências a decisões da Côrte Suprema sôbre um ponto que hoje em dia constitui objeto de notoriedade popular e ao qual mesmo o homem da rua só se refere de passagem, como a uma dessas noções que se dão por óbvias ou pressupostas.

Entretanto, para que mesmo os obstinados não continuem a obstinar-se na dúvida, transcreveremos, a propósito da $14^{\mathrm{a}}$ emenda à Constituição dos Estados Unidos, e em cuja segunda parte se proibia aos Estados denegar a pessoas sob a sua jurisdição a igual proteção da lei, a interpretação que a essa cláusula deu a Côrte Suprema em ex parte Virgínia (100 U.S. 339-347): “A State acts by legislative, its executive, or its judicial authorities. It can't act in another way. The constitutional provision therefore must mean that no agency of the State, or the officers or agents by whom its powers are exerted, shall deny to any person within its jurisdiction the equal protection of the law".

Eis como o mais recente e mais copioso repertório do direito americano resume a torrencial e uniforme jurisprudência, assim dos tribunais dos Estados, como da Côrte Suprema: "Legislation may be limited in scope; and it may be adjusted to differences in things or situations; but it may not make any arbitrary or unreasonable distinction or discrimination; and within the sphere of its operation, it must accord substantially equal and uniform treatment to all persons similary situated" ("Corpus Juris Secundum", 1939, vol. 16, § 505, letra $b$ ).

Dir-se-á que a emenda $14^{\text {a }}$ à Constituição dos Estados só se aplica aos Estados, não constituindo, portanto, limitação aos poderes do Govêrno federal. Assim é, efetivamente, mas só na aparência. De fato, o princípio de igualdade perante a lei figura, igualmente, na $15^{\text {a }}$ emenda à Constituição dos Estados Unidos, a qual é concebida nos seguintes têrmos:

"No person shall be deprived of life liberty or property, without due process of law".

A emenda é uniformemente considerada como constituindo limitação constitucional ao Govêrno da União ("Corpus Juris Secundum", vol. 16, $\S 568$, letra b, Gooley, "Constitutional Limitations", 7ª ed., pág. 507; Willis, 
"Constitutional Law", 1936, pág. 653; Willoughby, "On the Constitution", vol. II, pág. 856). A cláusula relativa ao due process of law tem sido interpretada, sem discrepância, como incluindo a proibição ao Poder Legislativo de editar leis discriminatórias, ou em que sejam negócios, coisas ou pessoas tratadas com desigualdade em pontos sôbre os quais não haja entre elas diferenças razoáveis, ou que exijam, por sua natureza, medidas singulares ou diferenciais. A lei não poderá discriminar senão quando haja fundadas razões de fato, que indiquem a existência de diferenças reais. Ora, onde a discriminação já é um dado de fato, a lei que reconhece a diferença, para tratar cada caso de acôrdo com a sua natureza específica, não está, efetivamente, discriminando. Quando, porém, a lei discrimina pessoas, fatos, negócios ou atos, entre os quais existe identidade ou igualdade de condições gerais, por pertencerem a uma mesma classe, categoria ou ordem, a lei está discriminando, contra a proibição constituocional.

"It has been repeatedly declared that the enactment of a legislature directed against particular individuals or corporations, without any reasonable ground for selecting them out of the general mass of individuals or corporations, amounts to a denial of due process of law far as their life, liberty or property disaffected. One of the requirements of due process of law, as stated by the Supreme Court, is that "the laws operates on all alike, and do not subject the individual to an arbitrary exercise of the powers of government" (Willoughby, "On Constitution", vol. II, pág. 874; Willis, "Constitutional Law", págs. 653 e 654).

Cooley, referindo-se à aplicação da cláusula relativa ao due process of law como coincidindo com a equal protection of the law, assegurando, pois, em relação ao Govêrno federal, o mesmo direito que a última garante em relação aos governos dos Estados, isto é, o princípio de igualdade perante a lei, escreve: "But a statute would not be constitutional if it prescribes a class or a party for opinions sake, or if it selects particular individuals from a class or locality, and subjet them to peculiar rules, or impose upon them special obligations or burdens from which others in the same locality or classes are except" (Cooley, op. cit., págs. 556 e 557).

Condensando a jurisprudência de quase um século, sobre o sentido, o alcance ou o conteúdo da due process clause, o "Corpus Juris Secundum" dá as seguintes súmulas:

"The government, and every one of its branches, agencies and subdivisions are bound by the prohibition of the due process guaranties " (vol. 16, § 568, letra $e$ )

"The constitutional garanty of due process of law is intented to protect the individual against arbitrary exercise of governmental power and secure to all equal protection of the law" (idem, idem, $\S 569$, letra $a$ ). 
Não há dúvida, portanto, de que nos Estados Unidos a Constituição consagra, mediante o due process of the law, a igualdade perante a lei. Na Suíça, igualmente, é ponto pacífico de doutrina, com esta, em relação àquele ponto, coincidindo a jurisprudência, que o princípio constitucional de igualdade perante a lei vincula o legislador, não podendo a lei distinguir onde não cabe ou é arbitrária a distinção, não lhe sendo lícito, outrossim, aquinhoar a um indivíduo com vantagem que não torna igualmente extensiva aos demais que se encontram na mesma situação, ou onerar a um mais do que a outro ou outros, em relação aos quais se verifica identidade de estado, de circunstâncias, de atividade, de profissão ou de negócio. Assim, dentre várias decisões do Tribunal Federal Suíço, citarei a seguinte, que é apenas uma típica amostra da sua copiosa jurisprudência sobre a matéria:

"Das in Artikel 4 der Bundesverfassung niedergelegte Prinzip ist als grundsätzliche Norm sowohl für die verwaltende und richterliche, als auch für die gesetzgericte Tätigkeit der Staatdbshörden massgehend. Es wird dadurch sowohl gleiche Anwendung der Gesetze auf alle Bürger als auch Behandlung der selben durch den Gesetzgeber gefordert" ("Entscheidungen des Schweizen Bundesgerichts ", vol. 6º, pág. 172).

\section{A tese contrária de Anschütz; refutação de Stier-Somlo, Kaufmann, Triepel, W. Jellinek e Schmitt}

Na Alemanha, sob a vigência da Constituição de Weimar, em cujo art. 109 se encontrava consagrado o princípio da igualdade perante a lei, Anschütz ficara solitário com a sua opinião de que o princípio de igualdade não constituía uma limitação ao legislador, mas uma norma de exclusiva obrigatoriedade para as autoridades incumbidas de aplicar a lei (Anschütz, "Die Verfassung des Deutschen Reichs", 14a ed., comentário do artigo 109, no 2). De acôrdo com a doutrina de Anschütz, a parte primeira do art. 109 da Constituição de Weimar - em que se diz: "Alle Deutsche sind vor dem Gesetze gleich" - não teria sentido, pois só se aplicaria quando se tornasse desnecessária a sua aplicação por haver a própria lei disposto de modo igual para os casos iguais. Desde que o legislador, porém, no uso da discrição, que lhe reconhece Anschütz, houvesse tratado de modo desigual, ou mediante discriminação arbitrária, pessoas, estados de fato, ou negócios iguais, estaria exercendo uma faculdade constitucional, e às autoridades incumbidas de aplicar a lei faleceria a necessária competência para modificá-la, com o fim 
de a conciliar com o princípio de igualdade. Além disto, cumpre notar que tal doutrina é incompatível com os regimes autênticamente constitucionais. $\mathrm{E}^{\prime}$ uma reminiscência do poder soberano do princípio e do conceito da lei como ato discricionário da sua vontade. E', em suma, o absolutismo do Parlamento substituindo ao absolutismo do príncipe, ou o primeiro como imediato sucessor e continuador do segundo. Onde, porém, existe um regime constitucional, a vontade do Parlamento não é lei, pela simples razão de ser um ato de sua vontade, mas tão sòmente porque é uma deliberação tomada na conformidade das normas constitucionais. A tese de Anschütz não encontrou eco na ciência alemã do direito. Contra ela se manifestaram os mais eminentes professores de direito constitucional, não apenas de modo dogmático ou pelo simples pêso da sua autoridade, mas cumpridamente, analiticamente e pelas mais poderosas razões de ordem jurídica. Já tivemos oportunidade de referir a opinião de Stier-Somlo, no ensaio que escreveu para a obra em que colaboraram quase todos os maiores especialistas da Alemanha, sob o título "Grundrechte und Grundpfliehten der Reichsverfassung" cujos três grossos tomos se ocupam exclusivamente da declaração de direitos na Constituição de Weimar. Na reunião celebrada em Münster, em 29 e 30 de março de 1926, pelos professores de direito público nas Universidades da Alemanha ("Vereinigung der Deutschen Staatsrechtslehrer"), o tema submetido à contravérsia foi, precisamente, o da igualdade perante a lei e o sentido de tal princípio tal como consagrado no art. 109 da Constituição de Weimar. Os debates foram iniciados por Erich Kaufmann, professor em Bonn. Sôbre a questão fundamental de saber qual o destinatário do mandamento constitucional relativo à igualdade, eis como se pronunciou, depois de aduzir as mais poderosas razões, o professor Kaufmann: "Ursprung und Sinn des Satzes von der Gleichheit von dem Gesetz zeigen das in ihm ein Rechtsprinzip aufgestellt sein sollte. Das überpositiv gilt. Darum richtet er sich vor allem und in erster Linie an die Adresse des Gesetzgebers, der berufen ist geschriebenes Recht zu schaffen und dies dabei dies Rechtsprinzip nicht verletzen darf. Nur wenn gewisse oberste Principien nicht verlezt worden sind schafft das Gesetz wirklich Recht.

Die Grundrechte enthaltenden Verfassurgssätze sollen Richtschnur und Schranke sein sowohl für die Gesetzgebung wie für die mit der Gesetzanwendung betrauten Behörden" (Erich Kaufmann. "Gleichheit vor dem Gesetz", no caderno 3을 das "Voröffentlichungen der Vereinigung der Deutschen, Staatsrechtslehrer". 1927.págs. 5 e 6). 
O professor Triepel, Berlim, comentando a dissertação de kaufmann, concordou com êste em que o princípio constitucional de igualdade obriga, vincula e limita o legislador. Partindo do fato de que o sistema constitucional da Alemanha havia sofrido uma profunda alteração no sentido democrático, e que ao invés de ser uma sistema singular ou isolado, tinha os seus caracteres fundamentais em comum com os outros sistemas de Constituição e que tal coincidência se reproduzia com freqüência no mundo civilizado, concluía Triepel: "Unser Recht ist doch nicht isoliert, sondern steht mit der gesamten Kultur der Gegenwart in Zusammenhänge laufen um die ganze zivilisierte Welt. Und gerade weil sich der neue deutsche Bau auf den demokratischen Untergrund stellt, ist es kein Missgriff, wenn man die neue deutsche Rechtsordnung in Beziehung setzt zu dem Rechtssystem der Vereinigten Staaten oder der Schweiz, wenn man Argumente, die auf dem Boden der fremden Rechtsordnung gebraucht sind, mit gewissen Vorbehalten natürlich, auch für unser Recht verwendete" (Triepel, Veröffentlichungen der Deutschen Staatsrechtslehrer" (Triepel, "Veröffentlichungen der Deutschen Staatsrechtslehrer", Heft, 3, pág. 50).

Walter Jellinek, no seu tratado de direito administrativo, propõe a questão de se o princípio de igualdade perante a lei se destina a reger apenas a aplicação da lei ou se rege, igualmente, o legislador, proibindo-lhe editar leis arbitrárias ou para casos determinados, isto é, ao invés de tomar como critério para a formulação da regra uma classe de relações, toma uma determinada relação, excluindo as demais da mesma classe do regime que decreta para aquela. Depois de expor os argumentos pró e contra cada uma das soluções, conclui no sentido de ser mais razoável atribuir-se ao princípio de igualdade a significação mais ampla, ou a que o torna obrigatório para o legislador. A principal razão apresentada por W. Jellinek é que constitui um princípio fundamental do direito o de que êle não deve ser contraditório consigo mesmo, e o seria, certamente, se aos funcionários se proibissem atos de arbítrio e de parcialidade e ao legislador se facultasse a prática dos mesmos.

"Nach allem Abwägen des Für und Wider muss man dem Gleichheitsartikel die weitere Bedeutung geben. Denn es ist doch wohl ein unbestrittener Grundsatz des Rechts, dass es nicht in sich selbst widerspruchsvoll sein soll. Das Recht wäre es aber, wenn Unsachlichkeit, Willkür der Verwaltungsbehörde verboten, dem Gesetzgeber aber gestattet sein sollte" (Walter Jellinek, "Verwaltungsrecht", pág. 155).

Carl Schmitt, cuja autoridade na interpretaçao do direito constitucional vigente na Alemanha até janeiro de 1933, quando a revolução nacional-socialista destruiu a Constituição de Weimar, não era menor do que a autoridade que lhe é universalmente reconhecida no domínio do direito público geral, considerou 
a questão ao seu modo particular, que consiste em ir às raízes e, com a concisão e a luminosidade da sua linguagem, tornar explícitas as razões profundas em virtude das quais uma norma ou um princípio constitucional, aparentemente isolado ou singular, constitui uma peça essencial do sistema da Constituição ou a chave de abóbada do regime jurídico-político por ela instituído. E' o que fêz em relação ao princípio de igualdade perante a lei, revelando as conexões íntimas e profundas, por fôrça das quais, na sua significação ou no seu conteúdo, se contém o critério fundamental ou sistemático, que caracteriza o tipo de Estado que se denomina comumente Estado de direito (Rechtsstaat).

Assim, propondo-se a questão de se o princípio de igualdade perante a lei é um mandamento que se dirige ao legislador ou às autoridades incumbidas da aplicação da lei, Schmitt não tem dúvida em afirmar que o destinatário daquele mandamento é precisamente o legislador, e que o conteúdo de direito positivo do artigo da Constituição, no qual se enuncia o princípio de igualdade, consiste na proibição ao legislador de editar leis que contenham disposições individuais ou concretas contra pessoas determinadas. O princípio, continua Schmitt, não teria conteúdo algum se não se lhe atribui o sentido ou a finalidade de vedar ou impedir a legislação, por via de medidas de caráter individual ou de ordens ou decisões sôbre casos concretos. Se, com efeito, a lei pudesse consistir em decisões ou ordens sôbre casos particulares ou individuais, não haveria razão para atribuir ao princípio de igualdade a exclusiva função de reger os atos de execução ou de aplicação das leis. Ou a lei disporia de modo geral, ou para todos os individuos, negócios ou relações da mesma ordem ou da mesma classe - e neste caso, não seria necessário recorrer ao princípio da igualdade para aplicá-la igualmente a todos os indivíduos da classe ou da ordem por ela contemplada - ou a lei consistiria em uma medida de caráter individual ou concreto, destinada a se aplicar tão-sòmente ao caso ou casos nela regulados, e, em tal hipótese, não teria sentido propor-se como critério regulativo de uma lei de exceção precisamente o princípio que a lei ostensivamente e de modo manifesto viola ou repudia. Quando a lei visa apenas a um indivíduo ou a algunas indivíduos, seria disparatado, a não ser que o princípio obrigasse o legislador, e, precisamente, para condenar a medida apòcrifamente legislativa, falar-se em igualdade perante a lei. Assim, o princípio: "Todos os alemães são iguais perante a lei" não pode, evidentemente, significar: "Tôdas as leis devem ser cumpridas" ou "Todos os alemães estão sujeitos à lei". A sua única e exclusiva significação só pode ser a de que todos estão igualmente sujeitos à lei. De onde resulta que a lei deve ser formulada de maneira a se tornar possível a igualdade perante as suas disposições. 
Se a lei se reduz a uma ordem, a um comando ou a uma decisão de caráter concreto ou individual, ela será o que denominamos ordinàriamente, quando queremos nos referir a um ato da administração, uma medida, e não uma lei, no seu sentido do princípio da igualdade. Igualdade perante uma medida é um contra-senso ou um pensamento sem conteúdo lógico.

Finalmente, Schmitt considera o princípio de igualdade perante a lei o próprio fundamento do Estado de direito: "Hier zeigt sich, dass die Gleichheit vor dem Gesetz in der Tat die eigentliche des Rechtsstaats und die wirksamste Garantie gegen jeden Despotismus bedeutet. Ohne diese Gleichheit konnte die Gesetzform zu jeder Ungerechtigkeit missbraucht werden und würden alle verfassungsmässigen Einrichtungen und Zuständigkeitsregelungen sich in Nichts auflösen" (Carl Schmitt, no parecer que emitiu sôbre a liquidação dos bens das antigas casas reinantes da Alemanha e publicado sob o título "Unabhängigkeit der Richter, Gleichheit vor dem Gesetz und Gewährleistung des Privats - Eigentums nach der Weimarer Verfassung", Berlin und Leipzig, 1926, págs. 22 e 23).

\section{Inconsistência dos argumentos de Anschütz}

Nos últimos anos de vigência da Constituição de Weimar, Anschütz era, dentre os especialistas em direito público na Alemanha, talvez o único que permaneceu aferrado a um ponto de vista que havia sido superado pelos acontecimentos, que operaram a transformação das instituições políticas alemãs depois da primeira guerra mundial e antes que o nacional-socialismo houvesse conquistado o poder. Anschütz não se apercebeu das conseqüências políticas e jurídicas que, necessàriamente, teriam de resultar da adoção pela Alemanha de um regime democrático e liberal e, sobretudo, de uma Constituição, cujo centro de gravidade se encontrava precisamente situado na parte da Constituição em que vinham declarados os direitos fundamentais. Êle continuou a ter por válidos conceitos juridicos que a nova ordem de coisas havia tornado denitivamente peremptos. Assim, quando enfrentou a tarefa de comentar a Constituição de Weimar, o velho professor procurou servir-se dos obsoletos instrumentos científicos ou dos conceitos que a ciência jurídica havia formulado para estudar, analisar e classificar urna realidade política, que se havia sumido por entre os destroços de instituições econômicas, políticas e jurídicas, destruídas pela primeira grande crise mundial que assinalou, nos nossos dias, o começo de uma nova época, ou melhor, de uma nova era 
da história universal. Continuando a ver o presente através das categorias do passado, quando entre os dois se estabelecia uma relação polar, de alta tensão ou de profundo conflito ideológico, o grande mestre parecia ver na Constituição de Weimar uma simples nova versão da velha Constituição prussiana, apenas mais adornada do que esta e com aparência enriquecida pela inflação verbal da nova moda democrática. Daí o isolamento em que ficou a sua singular opinião de que o princípio constitucional de igualdade não constitui um mandamento endereçado ao legislador ou destinado a limitar o seu arbítrio. Os demais professôres de direito público deixaram para trás o veterano da sua ciência, o qual se mantinha fiel a uma ordem de coisas contemporânea da sua juventude.

A opinião de Anschütz, de que o princípio de igualdade obriga tão-sòmente os funcionários incumbidos de aplicar a lei, passou a ser na Alemanha uma opinião solitária, ou que não é compartilhada por nenhuma das grandes autoridades em direito público alemão ou em direito público geral. Ou, como diz Nawiasky: "Diese Ansicht wird heute wohl nirgends mehr vertreten werden" ("Veröffentlichungen der Vereinigung der Deutschen Staatsrechtslehrer", Heft, 3, pág. 62).

Stier-Somlo acentua, igualmente, que, não só pela eminência, como pelo número dos professôres de direito público na Alemanha que professam opinião oposta à de Anschütz, se pode considerar vencedor o ponto de vista de que o princípio constitucional de igualdade constitui, de modo principal, senão exclusivo, um limite à atividade, até então tida como discricionária, do Poder Legislativo, em matéria de legislação.

"Von einer hervorragender, auch zahlenmässig stark zugenommenen Gruppe namhafter Staatsrechtslehrer wird jedoch in den letzten Jahren dem Art. 109 I eine Auslegung gegeben, die von verschiedenen Seiten her den G1eichheitssatz auch gegenüber der Gesetzgebung duchgeführt wissen will" (Stier-Somlo, "Gleichheit vor dem Gesetz", em "Grundrechte und Grundpflicten der Reichsverfassung", vol. I, pág. 178).

É verdade que Anschütz, no seu livro de comentário à Constituição de Weimar, reconhecendo o fato de ser cada dia maior o número de autoridades contrárias à sua opinião, escreve que essa circunstância não constitui argumento, pois se trataria, no caso, de opinião contra opinião, e as questões científicas não se decidem pela maioria de votos dos especialistas.

"Hier" (na ciência do direito) "steht, wiewohl nicht geleugnet werden soll, dass die Zhal der Schriftsteller, die sich su der neueren Lehre bekennen, im Wachsen begriffen ist, vorest noch Meinung gegen Meinung. Wissenschaftliche Streitfragen 
werden nicht durch Warheitsbeschlüsse der Fachleute entschieden" (Anschütz, "Die Verfassung des Deutschen Reichs", 14aㅜ ed., pág, 526).

Anschütz teria razão se se tratasse tão-sòmente de opor à sua afirmação a afirmação contrária dos seus opositores. Seria dogma contra dogma e o fato de um dos dogmas ser postulado por maioria de votos não constituiria argumento em favor da realidade ou da verdade do seu conteúdo. Mas não é êste o caso. Anschütz deu os fundamentos da sua opinião; tais fundamentos foram miudamente analisados, e demonstrou-se, de maneira irretorquível, que o seu ponto de vista, de que o princípio de igualdade é tão-sòmente um princípio regulativo a ser observado na aplicação da lei, tornaria sem sentido a cláusula constitucional, pois, na aplicação da lei o seu executor não pode modificar os seus têrmos e, se o pudesse, com o fito de fazer valer o princípio de igualdade, êste, contra a própria opinião de Anschütz, estaria sendo, efetivamente, aplicado ao legislador, com a agravante de que nesta aplicação o juiz poderia ser muitas vêzes uma autoridade inferior, a cujo critério, entretanto e em última análise, ficaria subordinado o próprio critério a que o legislador obedeceu na formulação da lei.

Examinando mais a fundo a opinião de Anschütz, os seus opositores mostraram, de modo cabal, que ela não resiste à prova da construção sistemática ou de conjunto, que é o único instrumento adequado ou eficaz de investigação do conteúdo e do sentido de uma cláusula constitucional tomada isoladamente, de modo particular quando nela se enuncia um princípio geral, cuja conexão com a estrutura íntima do sistema da Constituição resulta, de manifesto ou com a mais clara evidência, ainda de um exame superficial, incompleto ou sumário.

Examinemos, porém, discriminadamente, as razões apresentadas por Anschütz, para justificar a singularidade da sua perspectiva constitucional.

O seu primeiro argumento é que, se admitido ao princípio de igualdade perante a lei o valor ou a função de critério regulativo a ser observado pelo legislador, a legislação poderia ser objeto de exame pelo juiz, com a conseqüência de poder a justiça recusar-lhe aplicação, sob o fundamento de ser contrária ao princípio constitucional da igualdade, $\mathrm{O}$ argumento é, como resulta claramente, uma petição de princípio, pois Anschütz não demonstrou, como seria mister para que o seu argumento tivesse a fôrça que lhe empresta, a repugnância com a Constituição de Weimar da faculdade delegada à Justiça de pronunciar a inconstitucionalidade das leis. Ora, vigente a Constituição de Weimar, embora não constituísse ainda uma prática tão corrente como nos países de Constituição do tipo americano, reconhecia-se à Reichsgericht a 
faculdade de entrar no exame de se a lei era ou não constitucional, podendo recusar-se a aplicá-la, se, entre ela e a Constituição, fôsse manifesta a incompatibilidade. Isto em relação à Alemanha e à Constituição de Weimar. Quanto mais, porém, singular e estranho há de parecer o argumento de Anschütz, quando considerado na perspectiva da Constituição dos Estados Unidos e da nossa. A conseqüência, a que Anschütz atribui o caráter de uma desmarcada enormidade, é, para nós, uma das que decorrem de modo mais imediato e natural do nosso regime político e do tipo da nossa Constituição, ambos tradicionais na América e constituindo um traço distintivo da projeção no domínio da cultura política da concepção do mundo peculiar aos povos daquele continente.

Mais foi precisamente na Alemanha, em 1925, que o seu mais alto tribunal reconheceu que, não havendo, na Constituição de Weimar, qualquer vedação à Justiça de entrar no exame da constitucionalidade das leis federais, para recusar aplicação às que se revelassem manifestamente inconstitucionais, constitui direito e dever do juiz estender a sua investigação ao exame da conformidade entre as leis do Reich e a Constituição.

Mesmo para a Alemanha, ao tempo da vigência da Contituição de Weimar, o argumento de Anschütz não passava, como se vê, de uma opinião pessoal, mais inspirada no passado ou nas formas constitucionais pré-weimarianas do que no presente e na constelação das novas formas politícas e jurídicas recentemente emergidas da decisão do povo da Alemanha de se integrar, depois da derrota dos seus exércitos, na comunhão das nações de cultura liberal, ou em que a Constituição não é apenas um programa, mas um sistema de valores, com fôrça normativa para todos os poderes, por mais eminentes que êles sejam.

$\mathrm{O}$ argumento final de Anschütz, e que êle próprio considera de grande irnportância (sehr gewichtger), é que a Constituição assegura "a igualdade perante a lei" e não a "igualdade da lei". A partícula, na sua opinião, modifica de modo substancial o sentido e a extensão do princípio. "Igualdade perante a lei" seria a medida recomendada às autoridades, para se orientarem na aplicação das disposições legais; "igualdade da lei" seria a medida ou o critério que a Constituição daria ao legislador, para, na sua conformidade, formular os mandamentos da lei. A distinção é, como se vê, puramente bizantina, podendo filiar-se ao hábito, caracterìsticamente alemão ou muito freqüente na ciência alemã, de dividir e subdividir em espécies distintas, mediante critérios puramente formais, o que é, em si mesmo, ou substancialmente, uma só e mesma espécie. No fundo, as duas frases traduzem a mesma idéia. "A lei é igual para 
todos", "todos são iguais perante a lei" ou "todos têm direito à igualdade da lei" são variantes verbais do mesmo pensamento. Se, com efeito, todos são iguais perante a lei, é necessário que a lei a todos trate com igualdade, ou que o legislador adote, na formulação da lei, o critério de regular com igualdade ou de maneira igual para todos o que é comum a todos. Se a lei, ao contrário, regula de modo desigual o que deve ser tratado com igualdade, não poderá haver igualdade perante a lei, ou na fase da sua aplicação, pois, no caso, o que a lei quis, precisamente, foi discriminar de modo efetivo, ou pela sua aplicação, entre situações na realidade idênticas, iguais da mesma classe ou da mesma natureza. Assim, para que haja "igualdade perante a lei", é necessário que haja "igualdade da lei", e só no caso de haver "igualdade perante a lei" é que haverá, necessàriamente, "igualdade da lei". Em um e em outro caso, tanto na primeira como na segunda expressão, o que se enuncia é o pensamento de que a lei é igual para todos ou que o legislador não deverá aplicar às mesmas coisas ou às mesmas pessoas sistemas diferentes de pêso ou de medida.

Assim, não poderá subsistir qualquer dúvida quanto ao destinatário da cláusula constitucional da igualdade perante a lei. O seu destinatário é, precisamente, o legislador, e, em conseqüência, a legislação, por mais discricionários que possam ser os critérios da política legislativa, encontra no princípio constitucional da igualdade a primeira e mais fundamental das suas limitações.

No direito internacional, o princípio é também entendido como devendo reger a legislação, ou obrigar o legislador. Assim, no art. 75 do Protocolo de Genebra, sôbre a Alta Silésia, a regra da igualdade é desdobrada nas duas seguintes: “ $1^{\underline{o}}$ ) Leis ou regulamentos não podem conter discriminações contra uma minoria; $2^{\underline{o}}$ ) leis e regulamentos não podem ser interpretados ou aplicados com desigualdade". E a Côrte Internacional de Haia, no seu parecer de 10 de setembro de 1923, sôbre a minoria alemã na Polônia, declarou que era insubstancial que, no texto da lei polonesa, não fosse aparente a discriminação: "There must be equality in fact as well as ostensible legal equality; in the sense of the absence of discrimination in the words of the law" ("World Court Reports, a Collection of the Judgments, Orders and Opinions of the Permanent Court of International Justice", edited by Manley Hudson, Washington,·1934, vol. 1, pg. 218). 


\section{Aplicação do princípio de igualdade aos direitos, coisas e fatos}

$4^{\mathrm{o}}$ ) Impõe-se, finalmente, para que seja completo o exame do conteúdo do princípio constitucional de igualdade perante a lei, resolver uma última questão. O princípio de igualdade só se refere às pessoas, ou deve, também, reger a regulamentação legislativa dos direitos, das coisas e dos fatos? Ainda neste ponto, a tão conhecida Gründlichkeit dos especialistas alemães não poderia deixar de se fazer sentir, com o extraordinário radicalismo que caracteriza os critérios puramente formais, sob cuja incidência as coisas mais unidas e mais simples se decompõem num espectro de distinções, divisões e subdvisões, que impedem a percepção da unidade fundamental da sua natureza.

Assim, Nawiasky ("Veröffentlichungen der Vereimigung der Deutschen Staatsrechtslehrer". Heft 3. pág. 36) e Anschütz ("Verfassung des Deutschen Reichs", $14^{\text {a }}$ ed., comentário ao art. 109, I) distinguem, na igualdade perante a lei, entre as pessoas e as coisas ou os fatos, entre os direitos da personalidade e os demais direitos, achando que o princípio constitucional se refere aos direitos da personalidade e não aos outros. O que, portanto, se contém no princípio de igualdade é, tão-sòmente, a norma que proíbe fazer discriminação entre as pessoas, com fundamento no fato de não serem do mesmo sangue, do mesmo credo religioso ou político, ou de equivalente posição social ou de fortuna. A lei poderá, porém, regular de modo desigual fatos, relações jurídicas, coisas ou situações que não tenham incidência direta sôbre a entidade metafísica que é a personalidade humana.

Pondo de lado as dificuldades insolúveis, que se apresentariam em cada caso concreto, para a distinção entre direitos da personalidade e os outros direitos, e o arbítrio que de tal critério resultaria conferido à legislação, à Justiça e à Administração, quanto à ponderação dos direitos do ponto de vista da sua incidência direta ou indireta sôbre a substância da personalidade humana, ou sôbre os seus atributos mais ou menos essenciais ou secundários, a distinção que Nawiasky e Anschütz procuram projetar, do nimbo da sua própria metafísica para o plano do direito constitucional positivo, não encontra fundamento nem na Constituição, nem na ciência do direito. Efetivamente, o direito só regula os fatos, as coisas, as situações em vista das pessoas, ou tendo as pessoas como foco de incidência final da regulamentação. O direito, em outras palavras, não incide diretamente sôbre a pessoa; sòmente através das coisas, das atividades, dos atos, dos fatos e das situações é que êle atinge a pessoa, ou a personalidade humana. Não existe, portanto, como querem Anschütz e Nawiasky, persönliche Gleichheit (igualdade pessoal) e sachliche 
Gleichheit (igualdade quanto às coisas ou aos estados de fato regulados pelo direito). A lei pode, com efeito, estabelecer desigualdade entre as pessoas, não só de modo subjetivo como de modo objetivo, ou mediante um tratamento desigual de relações em que as pessoas estejam para com fatos, coisas ou situações aparentemente estranhas à esfera da personalidade, considerada como o centro ideal de imputação das faculdades abstratas, em que costumamos decompor a complexidade real do homem empírico. Qualquer desigualdade, porém, que a lei venha a estabelecer entre coisas ou fatos terá, necessàriamente, como foco de incidência a pessoa. Finalmente e em última análise, o direito regula as coisas ou os negócios porque e sòmente até o ponto em que as coisas e os negócios interessam as pessoas, e, mais ainda, o que se chama regulamentação objetiva, ou das coisas e dos fatos, é, no fundo e tão-sòmente, regulamentação subjetiva, ou das pessoas. Se, portanto, a lei regula de modo diferente coisas ou situações objetivas idênticas, o que ela, efetivamente, estabelece é a desigualdade entre as pessoas interessadas naquelas coisas ou naquelas situações, que só constituem objeto de regulamentação jurídica porque são situações ou coisas suscetíveis de se configurarem como objeto da vontade ou da ação do homem. Foi o que Triepel, na reunião dos professôres alemães de direito público, celebrada em Münster, em 1926, objetou, de maneira irrespondível, à tese metafísica de Nawiasky e de Anschütz.

"Insichitlich des lnhalts des Art. 109 satz 1 zweifele ich, dass man eine scharpe Sonderung zwischen persönlicher und sachlicher Gleichheit annehmen kann; man kann das gar nicht durchführen. Das Recht ist eine Ordnung menschlichen Zusammenlebens. Jeder Tatbestand hängt mit einer Person zusammen, jedes sachliche Verhältnis hat auch eine persönliche Seite. Das Sachliche und das Persönliche lässt sich voneinander gar nicht trennen. Man kann natürlich sagen, ein Gesetz könne zunächst an das eine oder zunächst an das andere anknüpfen" (Triepel, "Veröffentlichungen der Vereinigung der Deutschen Rechtsstaatslehrer", Heft 3, pág. 5)

Êste mesmo ponto de vista, de que o princípio de igualdade não se limita a assegurar a igualdade genérica dos homens, ou a igualdade fundada no fato de que em todos os homens há um fundo comum, que denominamos personalidade humana, mas se estende, igualmente, a todo o campo da regulamentação jurídica, pela óbvia razão de que a finalidade, assim próxima como remota do direito é a pessoa, Triepel já o havia sustentado, no parecer que emitiu sôbre "Goldbilazverordnung und Vorzugsaktien, ein Rechtsgutachten", 1924, págs. 26 e segs.

Stier-Somlo endossa de maneira integral o ponto de vista de Triepel (StierSomlo, "Gleichheit vor dem Gesetz", em "Grundrechte und Grundpflichten der Reichverfassung", vol. I. págs. 179 e 180). 
Aldag ("Gleichheit vor dem Gesetz", pg. 51) considera que o princípio de igualdade tem por conteúdo precisamente a norma que prescreve deverem fatos (Tatbestände) iguais ser regulados de modo igual: "Der Satz. "Alle Deutschen sind vor dem Gesetz gleich" bedeut, dass in Gesetzgebung Verwaltung und Rechtssprechung gleich Tatbestände gleich behandelt werden müssen".

Na Suíça, o Tribunal Federal considera, igualmente, que o princípio constitucional de igualdade rege não sòmente o que se convencionou denominar direitos da personalidade como todos os direitos, fatos, estados de fato ou relações jurídicas de qualquer natureza (Stier-Somlo, op. e vol. cits. págs. 180)

Nos Estados Unidos, a cláusula relativa à equal protection of the law tem por conteúdo tôdas as modalidades da atividade humana, assim o gôzo dos direitos pessoais como dos direitos civis (enjoyment of personal and civil rights).

Justice Field definiu, de modo magistral e com a maior amplitude, todo o campo de incidência do princípio de igualdade, ao pronunciar a decisão da Côrte Suprema no caso Barbier v. Connolly: "not only that there sould be no arbitrary deprivation of life or liberty or arbitrary spoliation of property, but that equal protection and security should be given to all under the same circunstances in the enjoyment of their personal and civil rights; that everybody / all people, should be equally entitleid to pursue their happiness to acquire and enjoy property; that they should have similar access to the courts of the country for the protection of their people and property; [..] that no inpediment should be interposed to the pursuit of anyone except as applied to the same pursuits by others under similar circumstances; that no greater burdens should be laid upon one than are laid upon another in the same calling and condition" (113 U.S. 27, 31, 32).

Em resumo, pois, o $\S 1^{\text {o }}$ do art. 141 da Constituição de 1946 significa simplesmente que o legislador deverá tratar como igual aquilo que (pessoa, fato, contrato, coisa ou estado de coisas, relação jurídica de qualquer espécie) seria arbitrário tratar como desigual. Desde que, ao regular um ato, um fato, uma atividade, ou ao criar um direito ou uma obrigação, a lei prescreva um determinado regime jurídico para um, sem que o estenda a todos os demais da mesma classe, está violando o princípio constitucional da igualdade perante a lei, e é, assim, uma lei inválida ou ineficaz.

\section{Conceito de lei como disposição de caráter geral}

Do fato de conterem as Constituições líbero-democráticas uma declaração de direitos fundamentais, não com o caráter de simples programa destinado 
a orientar a legislação, mas como norma de direito constitucional positivo, cuja estrita observância se impõe ao Estado - à legislação, à Administração e à Justiça - segue-se uma conseqüência da mais alta significação, que é o conceito de lei como disposição de caráter geral, ou como regra de direito, e, portanto, a vedação, ao Poder Legislativo, de legislar por via de medidas individuais ou concretas. Assim, em tais regimes, nem todo ato do Poder Legislativo é lei; lei será, tão-sòmente, o ato do Poder Legislativo em que vem formulada uma regra de direito a ser aplicada a um número indeterminado de casos.

a) Êste, aliás, é o conceito tradicional da lei, o que se encontra definido nos tratados de política, nos livros de direito público, assim como nos consagrados ao estudo do direito civil.

As raízes de sua tradição se encontram na filosofia política dos gregos e na doutrina dos jurisconsultos romanos. Já na "Política", de Aristóteles, se encontra enunciado o princípio de que "a lei sempre dispõe por via geral e não para os casos acidentais ou particulares". Papiniano (frag. 1, Digesto de Legibus, I, 3) assim define a lei "Lex est commune praeceptum"; Celso (Digesto, frag. 4, mesmo título) declara que as leis não se estabelecem com o fim de reger o casual, acidental ou fortuito: "Ex his quae forte uno aliquo casu accidere possunt, jura non constituuntur", e Ulpiano (frag. 8, mesmo título): "Jura non in singulas personas, sed generaliter constituuntur". Para Rousseau, a lei é a expressão da vontade geral, não sòmente no sentido de que deve ser a expressão da vontade geral, ou comum do povo, como também no sentido de que o seu conteúdo deve ser uma regra de caráter geral, ou que tenha por objeto o interêsse geral ("Contrat Social", liv. II, cap. VI). Portalis, em seu discurso preliminar sôbre o Cód. Civil francês, declara: "La loi statue sur tous; elle considère les hommes en masse, jamais comme particuliers; elle ne doit point se mêler des faits individuels. La loi est une déclaration solennelle de la volonté du souverain sur un objet d'interêt commun". Blackstone define a lei como "une règle, non pas un ordre subit et transitoire relatif à un particulier, mais une certaine disposition permanente, uniforme et universelle".

Entre os modernos, continua o conceito de lei a ser o mesmo que Aristóteles e os jurisconsultos romanos já haviam formulado. Assim Jèze conceitua a lei como "l'acte legislatif par lequel est formulée une régle de droit générale, impersonelle" ("Principes Généraux de Droit Administratif", página 56); Barthélémy ("Rôle du Pouvoir Executif dans les Républiques Modernes", pág. 10) escreve que "le pouvoir legislatif exprime sa volonté dans une générale". Bhuntschli ("Droit Public Général", pág. 86) considera que "la loi et l'administration s'opposent 
comme la volonté générale et la volonté particulière, comme l'ordre général et la disposition spécial"; Otto Mayer ("Droit Administratif", vol. I, pág. 4) entende por legislação "L'établissement par le souverain de règles gérérales et obligatoires"; Mayer ("Lehrbuch des Deutschen Staatsrecht", 7aㅡ ed., 1917, voI. II, pg. 640) observa que, em regra, a lei, em sentido material, se destina a regular uma pluralidade de casos, ou a ser aplicada a todos os casos em que se realiza o estado de fato (Tatbestand) por ela definido de maneira abstrata só havendo lei para um caso determinado ou concreto, quando, por natureza ou definição, o caso em si mesmo é único, singular, ou não possam ocorrer, na mesma espécie, outros casos que com êle tenham relações de analogia, semelhança ou identidade, como na hipótese de uma lei que regula a sucessão ao trono, para o caso em que venha a faltar o soberano que o ocupa no momento, ou na hipótese de uma lei que prorroga o período de uma sessão do Parlamento.

Duguit ("Traité de Droit Constitutionnel", 2. a ed., vol. II, pgs. 140 e segs.) depois de discutir exaustivamente o conceito de lei, admite a divisão comum em lei material e lei formal, conceituando, porém, como lei em sentido próprio, ou em sentido material, "la disposition par voie générale et abstrate; la disposition voie individuelle et concréte n'est par une loi au sens matériel; elle est une loi au sens formel si elle émane de l'organe legislatif; au point de vue matériel, elle sera, suivant les circonstances, un act administratif ou un act jurisdictionel" (pág. 146).

Quase nos mesmos têrmos em que Duguit a define, a lei, para Esmein ("Droit Constitutionnel", vol. I, pág. 22), é "une règle imperative ou prohibitive posée par le souverain, qui statue non dans un interêt particulier, mais dans un interêt commun, non à l'égard d'un individu isolé, mais à l'égard de tous pour l'avenir et à toujours".

No direito civil, não é outro o conceito de lei admitido pela generalidade dos autores. Planiol ("Traité Elémentaire de Droit Civil”, 6ª ed., vol. I, pág. 64) considera como lei apenas a disposição "établie en permanence pour un nombre indeterminé d'actes et de faits; toute décision de l'autorité publique qui ne doit être executé qu'une fois, n'est pas une loi, c'est un acte d'administration". Capitant ("Introduction à l'Etude du Droit Civil" 2ª ed., pág. 35) define a lei como sendo "une règle générale et abstraite, c'est-à-dire, qu'elle est faite non pour une espèce particulière, mais pour tous les cas où le rapport qu'elle reglemente se réprodura".

As proposições jurídicas que integram o conteúdo da lei são, na maioria dos casos, regras abstratas, isto é, estabelecem para um fato determinado de modo geral uma conseqüência jurídica igualmente determinada de modo geral; assim não regulam relações jurídicas concretas, senão categorias totais de relações jurídicas (Ennecerus, "Tratado de Derecho Civil”, vol. I, § 32, 5). 
De todos os civilistas, porém, é Henri de Page ("Droit Civil Belge", 1933, vol. I, $\mathrm{n}^{\mathrm{o}}$ 174) quem, de maneira mais completa e mais precisa, define o conceito de lei: "Não se concebe uma lei que reja tão-sòmente alguns indivíduos, com exclusão de outros que se encontram na mesma situação, ou que só estatuam para um ato ou contrato determinado. Tais leis não seriam, em verdade, leis, mas medidas arbitrárias, destituídas de qualquer valor obrigatório, não obstante a forma de que se revestem. Tôdas as medidas que se originam do Poder Legislativo e que só se referem a um caso particular não são leis, em sentido próprio. São atos administrativos, atos de alta administração, não são leis ordinárias.

"A lei stricto sensu, a lei no sentido ordinário da palavra, é uma medida de ordem geral, permanente, e destinada a reger as relações de todos os cidadãos ou de tôda uma categoria dêles".

\section{O "Estado de Direito" e o conceito de lei}

b) Êsse conceito de lei, embora admitido uniformemente na doutrina, não constitui, todavia, uma limitação jurídica ao Poder Legislativo. E', por assim dizer, um conceito estatístico da lei, ou que toma como critério ou como base para distinguir a lei dos outros atos do Estado o fato de que, no maior número de casos, a lei se apresenta sob a forma de uma regra geral e abstrata, destinada a regular categorias ou ordens de relações reunidas, entre si, por laços de semelhança, analogia ou identidade. Impõe-se, porém, uma questão da mais alta importância teórica e prática, a propósito do conceito da lei no tipo particular de organização jurídica e política que se identifica correntemente sob a denominação de "Estado de Direito", isto é, a forma de Estado que tem como fundamento o postulado de que nenhum ato da autoridade pública pode ser arbitrário ou discricionário, devendo, ao revés, para se tornar jurìdicamente válido ou obrigatório, ser imputado a uma proposição de ordem geral, que é, precisamente, a lei.

O Estado de direito é o Estado em que tôdas as atividades, todos os atos e tôdas as divisões da autoridade pública, seja qual fôr o grau que ocupem na hierarquia política, ou a medida em que participem na elaboração da vontade do Estado, são regidas pela lei ou pelo direito. Sòmente, porém, um tipo particular de Estado de direito satisfaz plenamente ou de maneira total a êsse requisito. E' o Estado constitucional, e, mais particularmente, o Estado liberal, dotado de uma Constituição que não se limita a prescrever a organização ou 
a estrutura do Estado, mas regula, igualmente, a situação do indivíduo em relação ao Govêrno, criando àquele uma esfera própria de ação, ou um regime de autonomia, independência ou liberdade, constitucionalmente definido e protegido. Êsse será o Estado totalmente de direito, ou regido pelo direito na sua totalidade. $\mathrm{Na}$ ausência de uma Constituição dotada daqueles requisitos, o princípio de legalidade, embora aplicado à Administração e à Justiça, não poderia ser aplicado à legislação, por não haver, acima da lei, uma regra a cujos critérios ela pudesse ficar subordinada. No Estado constitucional, o princípio de legalidade regerá, igualmente, o Poder Legislativo, pois o ato dêste não valerá (assim como no simples Estado de direito o ato administrativo ou jurisdicional só é válido se de conformidade com a lei ordinária) se não puder ser imputado a uma norma constitucional, seja esta expressa ou resulte implìcitamente de norma constitucional expressa ou do sistema constitucional tomado no seu conjunto, na sua integralidade, ou como sistema dotado por fôrça dos seus princípios fundamentais de um sentido próprio e total, com influência sôbre o sentido das normas constitucionais concretas ou particulares. Sòmente em regimes ou em Estados dêsse tipo é que terá sentido a indagação de se existe um conceito de lei que não tenha tão-sòmente um valor estatístico, mas um valor jurídico, isto é, com a fôrça de se impõr ao Poder Legislativo como norma que lhe será obrigatório observar na formulação das leis ordinárias.

Em outras palavras, o problema consiste, de modo preciso, em saber se o conceito da lei decorre, necessàriamente, do tipo da Constituição, e qual deve ser, de acôrdo com o tipo da Constituição brasileira de 1946, o conceito da lei. O primeiro têrmo do problema enuncia a sua própria solução. Se a Constituição regula não sòmente a forma em que deve exercer-se a competência dos diversos órgãos do Estado, como o conteúdo ou a matéria dessa competência, dela deverá, necessàriamente, resultar um conceito particular do que se deve entender por lei no sistema constitucional em foco, ou quais os requisitos a que o ato do Poder Legislativo deverá obedecer, para que possa distinguir-se dos atos administrativos e jurisdicionais, ou ser considerado, independentemente do fato de ser um ato do Poder Legislativo, como lei pròpriamente dita, ou como lei em sentido próprio, ou no sentido que resulta do sistema constitucional concreto, tomado como centro de referência ou de imputação dos conceitos que o jurista procura formular sobre a base das suas normas particulares, ou dos princípios e postulados que decorrem da sua configuração total ou sistemática. Sòmente da Constituição pode decorrer um conceito positivo da lei. Não há, nem pode haver, com efeito, um conceito de lei que seja válido para tôdas as formas de Estado. Nem poderá ser considerado 
como válido, para um determinado tipo de Estado constitucional, o conceito de lei construído mediante a interpretação de conjunto ou sistemática de uma Constituição positiva de tipo diferente. Pode haver, por exemplo, um Estado em que, embora dotado de Constituição, não haja um critério pelo qual seja possível determinar, por caracteres intrínsecos, o que seja lei ou o que deva ser considerado lei nos termos do sistema constitucional positivo. Em tal sistema, a lei se caracteriza pelo órgão de que ela emana, ou o critério para distinguir a lei dos demais atos do Estado será puramente formal: lei será, nesse caso, todo ato editado pelo Poder Legislativo.

\section{Conceito formal de lei}

Contra êsse conceito formal da lei é que se levantou, em tôdas as épocas que haviam experimentado os horrores da tirania ou do govêrno arbitrário, o pensamento liberal, que reivindicava, como condição essencial não só da liberdade, como da justiça um conceito diverso da lei, ou a exigência de que a lei não seja tão-sòmente o ato editado pela autoridade suprema, pois, se assim fôsse, ela poderia vir a ser um ato arbitrário, ao mesmo título que é arbitrária uma decisão tomada pela autoridade pública para cada caso concreto e particular, mediante critérios puramente acidentais.

Na luta contra o arbítrio ou o absolutismo do poder viu-se, desde o princípio, que o conceito da lei constitui o principal escudo da liberdade e da justiça. A luta pela liberdade e pela justiça sempre se feriu em tôrno do conceito da lei. Nunca se perdeu de vista, em tôda a história da luta pela liberdade e pela justiça, que a medula da questão se encontrava, precisamente, no conceito da lei.

Conforme fôsse êste, ter-se-ia um Estado tirânico, um poder discricionário ou absoluto, ou, ao contrário, um Estado em que os atos das autoridades públicas, inclusive da autoridade suprema, poderiam ser aferidos, quanto à sua legitimidade, por uma medida, que, pelo seu caráter geral ou abstrato, impediria decisões fundadas em circunstâncias ocasionais ou fortuitas, sem relação com o interêsse comum.

O conceito de lei, como regra geral e abstrata, implicava duas exigências flmdamentais: em primeiro lugar, a exigência de que a autoridade suprema, cuja vontade se manifesta sob a forma de lei, só poderia tomar medidas de caráter público, ou no interêsse comum ou geral, e, em seguida, a exigência de que não pudesse tomar qualquer medida, com o fito de regular um caso 
determinado, ou de regular cada caso de acôrdo com um critério que só a êle se aplicasse, embora o caso em questão não fôsse o único da sua espécie ou tivesse em comum com outros, excluídos da aplicação da lei, os caracteres que a própria lei tomou como base para submetê-lo a um regime especial. Neste sentido é que Aristóteles distinguia entre democracia em que reina a lei e democracia em que prevalecem as decisões do povo ("Politique", liv. IV, cap. 4).

A lei, como regra geral, se opõe à decisão, como ato destinado a reger um só caso, uma única relação, ou um fato determinado, pelo que êle tem de particular, individual ou concreto. Sempre que se pretendeu restringir o arbítrio do Estado, contra êle se postulou, invariàvelmente, a exigência de que a autoridade não poderia tomar qualquer decisão, isto é, uma medida de caráter individual ou concreta, senão com fundamento em regra geral anteriormente editada por uma autoridade superior. Daí se originou o princípio da legalidade, ou a forma ainda rudimentar do Estado de direito.

De acordo com tal princípio, a Administração e a Justiça, que são órgãos de decisão e, portanto, sòmente agem por via de disposições individuais ou concretas, não podem editar nenhuma medida que não tenha fundamento em lei. Com isto, se pretendia pôr côbro ao arbítrio, precisamente no setor do Estado em que eram mais freqüentes as oportunidades de ação discricionária.

No princípio de legalidade da Administração e da Justiça parecia, em conseqüência, implícito o conceito de que a lei deveria conter uma regra geral, ou compreensiva de um número indeterminado de casos, consistindo a ação administrativa e jurisdicional tão-sòmente em subsumir sob a regra legal o fato que deveria constituir objeto da sua decisão. Esta se resumiria em aplicar ao fato uma regra que o Poder Legislativo não havia formulado ad hoc para êle, mas para a categoria, a ordem ou a espécie de fatos a que êle pertence. Do princípio de legalidade, assim entendido, o qual passou a constituir um traço distintivo do Estado moderno, é que se originou o conceito de lei, uniformemente adotado pela doutrina, como regra geral ou abstrata. Com êsse conceito, restringia-se o arbítrio do Estado no exercício das suas funções administrativas e jurisdicionais.

De como se vê a importância prática do conceito de lei, é que, em última análise, a garantia da liberdade será uma vã palavra, se a lei não é concebida como regra geral e abstrata, e não simplesmente como ato de vontade da Poder Legislativo.

A importância do conceito de lei como instrumento capital na luta contra o arbítrio do poder, resulta, de modo manifesto, na doutrina alemã, que estabeleceu a distinção entre lei em sentido material e em sentido formal. 
A origem dessa distinção se deve, particularmente, a circunstâncias de caráter histórico, ou, mais concretamente, às circunstâncias reinantes na Alemanha no fim do século passado. A Laband ("Droit Public de l'Empire Allemand", vol. II, págs. 516 e seguintes) e a Jellinek ("Gesetz und Verordnung”, ed. de 1919, págs. 226-261) se deve o conceito dúplice de lei em sentido material e em sentido formal.

De acôrdo com êsse conceito, é lei, em sentido material, o ato do Poder Legislativo que tem por objeto determinar a condição jurídica dos indivíduos, ou introduzir modificações na esfera da capacidade jurídica dos indivíduos, seja no seu estatuto pessoal, seja nos seus direitos patrimoniais, seja no domínio das liberdades individuais. Há, ao lado de leis dessa espécie, outras, que delas se distinguem por não terem os indivíduos como destinatários; delas não resulta a criação de direito ou encargo para o indivíduo, nem se destinam a modificar a órbita jurídica vigente. $\mathrm{O}$ seu destinatário é, precisamente, o Estado e o seu conteúdo consiste, precisamente, em disposições relativas à organização interna do Estado. Tais leis não constituem regras de direito; são leis em sentido puramente formal, ou tão-sòmente porque editadas pelo Poder Legislativo.

É visível que o intuito da doutrina era restringir o poder regulamentar que a Constituição do Império atribuía ao imperador (Carré de Malberg, “Théorie Générale de l'Etat", vol. I, no 102).

O fato, porém, é que o conceito de lei proposto por Laband e Jellinek, se constitui uma limitação ao poder regulamentar conferido ao chefe de Estado, nao constitui, entretanto, uma restrição ao Poder Legislativo, que poderá expedir, como lei ou com o valor de lei, medidas de caráter individual ou concreto. Uma lei, em sentido material, não será, portanto, na doutrina de Laband e Jellinek, sempre ou necessàriamente, uma regra geral, êles admitem que o Parlamento possa modificar, mediante uma lei especial, a esfera jurídica de uma pessoa. O conceito de lei em sentido material não constitui, em conseqüência, uma garantia contra a ação arbitrária do Poder Legislativo (Leon Duguit, em seu "Traité de Droit Constitutionnel", 2ª ed., vol. II, pags. 148 e segs).

Não se pode, entretanto, objetar ao conceito de lei formulado por Laband e por Jellinek o fato de não conciliar-se o mesmo com uma determinada concepção filosófica ou política ou de não se encontrar de acordo com certo tipo de Constituição ou Estado. Êstes o fomularam, com efeito, não de maneira teórica ou abstrata, mas tomando como ponto de referência o sistema constitucional então vigente na Alemanha. Ora, como já vimos, não pode existir um 
conceito jurídico abstrato de lei. O conceito de lei é um conceito eminentemente relativo ou histórico, de cada tipo ou sistema de Constituição decorrendo o que, de acordo com os seus princípios fundamentais, se há de entender como sendo o seu conceito próprio de lei.

\section{Conceito de lei na Constituição brasileira de 1946}

Cumpre-nos examinar, portanto, se a Constituição brasileira de 1946, assim como as demais Constituições do mesmo tipo, impõe um conceito definitivo e unívoco da lei. A resposta não poderá deixar de ser alternativa. O conceito da lei, seja êle qual fôr, é, efetivamente, um conceito fundamental. A lei é, de tôdas as formas de manifestações de vontade do Estado, a mais importante. Seria, portanto, de estranhar que um sistema constitucional, que é, precisamente, um sistema de organização jurídica do Estado, não contivesse, ainda que de maneira tácita, um ponto de vista definido sôbre o ato pelo qual se realiza, da maneira mais completa e mais eficaz, a imputação ao Estado, como se fôsse realmente dêle, da vontade individual de um homem qualquer ou de um grupo de homens quaisquer. O conceito de lei é, assim, e não poderia deixar de ser, um dos conceitos centrais do sistema constitucional.

Qual, portanto, o conceito de lei que resulta do nosso tipo de Constituição, isto é, de um tipo democrático e liberal de Constituição, ou de uma Constituição que não se limita a organizar o poder com o fim exclusivo de torná-lo capaz de ação, mas que o organiza de determinada maneira, não para que o poder seja mais poderoso ou menos limitado, mas, ao contrário, para que êle não possa exercer-se arbitràriamente, ou para que com êle, ou com a ordem do poder, possa conviver, assegurada a inviolabilidade da sua autonomia, a ordem da liberdade ou dos direitos indviduais. Em tal tipo da Constituição, o conceito de lei não pode ser o mesmo conceito que resulta de um sistema diferente de Constituição. Há de ser um conceito adequado ao tipo particular de Constituição, que postula, ao lado da ordem do poder, e acima desta ordem, a ordem da liberdade, ou a existência de uma esfera de ação reservada inteiramente à autonomia da vontade individual. O conceito de lei, em tal tipo ou sistema de Constituição, não pode deixar de ser o conceito de lei como regra

geral ou abstrata, ou a vedação, ainda que implícita, ao Poder Legislativo de editar, para a esfera reservada à liberdade ou aos direitos individuais, medidas que não sejam concebidas em têrmos gerais, ou que tenham como objeto, ao invés de uma classe ou de uma ordem de relações, casos concretos, 
particulares e determinados. Ou, em outras palavras, a lei não poderá regular para um só caso ou para um só indivíduo o que neste é comum com outros casos ou outros indivíduos. De outra maneira, a declaração de direitos seria apenas um discurso, sem qualquer alcance de ordem prática, e o seu enunciado na Constituição destoaria, de maneira evidente, da gravidade própria de um documento de tal natureza. De que valeria, com efeito, a declaração de direitos, se ao Poder Legislativo continuasse reservada a faculdade de intervir, mediante decisões ou ordens concretas, na esfera da liberdade individual, modificando o estatuto jurídico, pessoal ou patrimonial dos indivíduos, por fôrça de critérios parciais, ocasionais ou acidentais, ou com aplicação restrita a alguns casos ou a algumas pessoas, estabelecendo, assim, discriminações onde o que a Constituição entendeu garantir foi, precisamente, a ausência de discriminação?

Analisemos, com efeito, a declaração de direitos da Constituição brasileira de 1946, à luz do conceito formal da lei, como sendo pura e simplesmente um ato de Poder Legislativo, seja qual fôr o seu conteúdo e podendo em conseqüência limitar-se a uma medida de caráter estritamente individual, ou de restrita aplicação a uma pessoa ou a um fato, ou a um grupo de pessoas ou de fatos, com exclusão de outras pessoas ou de outros fatos, que tenham, com aquêles, relações de absoluta identidade, semelhança ou equivalência.

Assim, a Constituição brasileira assegura aos nacionais e aos estrangeiros residentes no país os direitos concernentes à vida, a liberdade, à segurança individual e à propriedade, nos têrmos seguintes:

"Art. 141, § $1^{\text {o }}$ Todos são iguais perante a lei".

Que sentido teria, com efeito, a igualdade perante a lei, se esta pudesse dispor por via individual ou se se reduzisse a uma medida concreta, de aplicação restrita a indivíduos ou situações, que a própria lei especificaria como sendo os exclusivos destinatários do seu mandamento? Diante de uma ordem ou de uma prescrição de caráter individual ou concreto, não tem sentido a exigência da igualdade, a não ser que se trate de uma decisão tomada em virtude de uma regra geral; neste caso, haveria uma medida comum, pela qual se poderia aferir, cotejar ou comparar o caso em questão com outros igualmente compreendidos na definição legal. Esta aferição não seria, porém, possível em relação à lei, se lei não fôsse, tão-sòmente, a regra de direito, ou a disposição jurídica formulada pelo Poder Legislativo, mediante critérios gerais, aplicáveis indiscriminadamente a um número indeterminado de pessoas, ou a tôdas as pessoas; indistintamente, e tão-só pelo fato de ser comum a elas a condição de que a lei faz depender a sua aplicação individual, concreta, ou a cada caso 
ou a cada pessoa em particular. O princípio de igualdade só tem sentido, com efeito, se há uma medida comum entre os casos ou as pessoas que devem ser tratados igualmente. Quando, portanto, a Constituição assegura o direito de propriedade a todos, ela só o assegura com igualdade, e ao Poder Legislativo é vedada a faculdade de alterar o regime jurídico da propriedade, a não ser de modo geral, em relação a todos os proprietários, e não, de modo especial, para um só proprietário, ou para determinados proprietários, por motivos estranhos à relação que possa existir entre o regime jurídico da propriedade e o interêsse comum ou geral da sociedade.

A nossa Constituição assegura, igualmente, a todos, nacionais e estrangeiros residentes no país, que

"Ninguém pode ser obrigado a fazer ou deixar de fazer alguma coisa senão em virtude de lei" (art. 141, $\S 2^{\circ}$ ).

Esta garantia não poderia ter qualquer sentido, se ao legislador fôsse facultado editar leis endereçadas exclusivamente a uma pessoa ou a um grupo de pessoas, ou se a lei não fosse uma regra de direito concebida em têrmos gerais e com enderêço indeterminado a uma categoria indeterminada de pessoas. De que poderia, com efeito, valer a um indivíduo aquela afirmação constitucional, se não fôsse a convicção, em que êle está, de que, em caso algum, o Poder Legislativo poderia criar tão-sòmenre para êle, ou com exclusão dos demais que se encontram em idêntica situação, um dever, um ônus, um encargo ou uma obrigação de fazer ou de deixar de fazer? De que valeria, por exemplo e para melhor concretizar a hipótese, a garantia de que nenhum impôsto me será exigido senão em virtude de lei, se amanhã o legislador poderá criar tão-sòmente para mim um tributo, de cuja incidência todos os demais indivíduos, nas mesmas condições, seriam, entretanto, isentos ou excluídos?

A garantia constante do $\S 2^{\circ}$ do art. 141 da Constituição só será, portanto, efetiva no caso em que, no conceito constitucional de lei, só se incluem os atos do Poder Legislativo que disponham por via geral, ou mediante o enunciado de uma regra ou de um preceito jurídico concebido em têrmos abstratos ou gerais, ou que compreenda os casos particulares, não porque os declara, enuncia ou menciona, mas porque os casos particulares pertencem à espécie, à categoria ou à ordem prevista pelo legislador como objeto ou conteúdo da nova norma que êle introduz no ordenamento jurídico da coletividade.

Assim em relação aos demais direitos ou garantias asseguradas no art. 141 da Constituição. Êsse artigo declara, por exemplo, que as associações religiosas adquirirão personalidade jurídica na forma da lei civil (§ $\left.7^{\circ}\right)$. Que significação se poderia atribuir a êsse direito, se, para cada associação, ou para as 
associações filiadas a cada confissão religiosa, uma lei especial prescrevesse formas ou exigências especiais, que variariam de rigor, ou que fôssem mais rigorosas para as associações católicas do que para as protestantes, ou inversamente?

Outra não seria a situação quanto à liberdade assegurada no § 14, em que se diz ser livre o exercício de qualquer profissão, observadas as condições de capacidade que a lei estabelecer. Se a lei não é uma regra geral, poderá, evidentemente, o legislador estabelecer, por meio de leis especiais, condições diversas de capacidade para o exercício da mesma profissão, como seria o caso se fizesse depender tais condições da localidade ou da região em que a profissão será exercida.

O § 15 declara que a casa é o asilo inviolável do indivíduo, e que ninguém poderá nela penetrar à noite, contra a vontade do morador, a não ser para acudir a vítimas de crimes ou desastres, nem durante o dia, fora dos casos que a lei estabelecer. Se a lei não é qualquer ato de Poder Legislativo, mas, tão-sòmente, o preceito que dispõe de modo geral, ou com igualdade para todos os casos, a garantia à inviolabilidade da casa terá sentido. Se o legislador, porém, pode editar leis sob a forma de decisões relativas a casos individuais ou concretos, a garantia em questão será um mero jôgo de palavras. A lei, nessa hipótese, poderia determinar de modo diferente para cada indivíduo ou para cada grupo de indivíduos, por caracteres que lhe fôssem absolutamente peculiares, e, sem qualquer relação com o fundamento da garantia de inviolabilidade do domicílio, os casos em que as suas casas, e tão-sòmente elas, poderiam ser penetradas ou invadidas sem o seu consentimento.

Que valor atribuir-se à garantia constante do $\S 20$, ou de que ninguém será preso senão em flagrante delito, ou por ordem escrita da autoridade competente, nos casos expressos em lei? Se lei é tão-sòmente o ato do Poder Legislativo que dispõe por via geral, a garantia tem sentido ou representa alguma coisa de sério ou de efetivo. Se, ao contrário, um ato do Poder Legislativo que dispõe por via individual ou para um caso concreto tem fôrça de lei, ou é lei ao mesmo título que a disposição por via geral ou para um número indeterminado de casos, então o § 20 será apenas uma bolha de ar, que o legislador constituinte teria assoprado com o exclusivo intuito de se distrair, por um momento, da aridez e das dificuldades da sua tarefa.

Como a lei é que determina, assim, os casos em que, fora da hipótese do flagrante, o indivíduo pode ser prêso, e qual a autoridade competente para expedir a ordem escrita, no caso de se ter como compreendido no conceito de lei qualquer ato do Poder Legislativo, êste poderia determinar diretamente a 
de um indivíduo, ou prescrever, para a prisão de negros, ou de comerciantes, ou de advogados, de acôrdo com as antipatias que nutrisse por um dêsses grupos, condições especialmente desfavoráveis para os indivíduos filiados ao que fosse escolhido pelo legislador como objeto da sua medida de exceção.

Assim, finalmente e em resumo, de todo o rosário das garantias asseguradas no art. 141 da Constituição se teria apurado que nenhuma delas fôra tomada a sério pelo legislador constituinte, que, ao enumerá-las, teve, apenas, a intenção de compôr, com bravura, uma fantasia literária, com o fim de quebrar a monotonia dos temas especificamente jurídicos da Constituição.

De onde resulta, a tôda evidência, que a garantia suprema, ou a garantia, que, em última instância, assegura e garante as garantias particulares constantes da declaração constitucional do art. 141, é o conceito da lei como regra geral ou abstrata, com enderêço indeterminado e conteúdo genérico, ou cuja disposição, por isso mesmo que devendo ser igual para todos, não pode individualizar o caso, senão pela referência à espécie, à classe lógica, à ordem de fatos ou de coisas, sob a qual êle se acha naturalmente subsumido, pelo fato de ter com um número indeterminado de outros casos de caracteres comuns que a lei toma como critério para indicar, circunscrever ou definir a matéria que ela entende regulamentar de modo imperativo, ou obrigatòriamente.

\section{A impossibilidade de discriminações arbitrárias, garantia máxima da declaração constitucional de direitos}

A garantia das garantias, ou a garantia sem a qual as garantias enunciadas na Constituição constituiriam meras frivolidades, que não mereceriam que ninguém dotado de algum senso-comum com elas se ocupasse, ainda que de passagem, é, precisamente, o fato de que a lei não poderá discriminar entre indivíduos, circunstâncias, ou estados de coisas, entre os quais não haja diferenças substanciais, quanto ao ponto que o legislador tomou como objeto da regulamentação legal.

Sòmente em virtude daquele fato é que se cria nos homens o sentimento de segurança em relação ao poder. $\mathrm{O}$ sentimento ou a convicção de que o poder não constitui um risco individual, ou de que o risco em que um incorre é incorrido pelos demais, é que, efetivamente, constitui a garantia fundamental, de cuja existência, embora implícita, na Constituição, resulta serem as garantias por ela expressamente asseguradas direito positivo, normas de restrição ou limitação ao poder, e não meras expressões verbais ou literárias, 
destinadas a criar uma falsa aparência de segurança contra os riscos a que o exercício do poder inquestionàvelmente expõe os indivíduos, ainda que a êles se confie a escolha dos seus agentes. A comunhão nos riscos, a igualdade quanto à sua incidência, ou o fato de os indivíduos se segurarem mùtuamente contra os riscos do poder, isto, e tão-sòmente isto, é que exclui o arbítrio no exercício da autoridade, a discrição nas medidas, a faculdade de excetuar o que não é excepcional ou singular, ou de onerar a uns mais do que a outros, de a algum ou a alguns proibir o que, em idêntica situação, se permite a outro ou a outros, de valer-se, finalmente, mediante a sua exclusão dos rigores de uma determinada medida, da cumplicidade passiva da maioria com um regime de preterição, injustiça ou desigualdade, a que o legislador entendesse de submeter a minoria, ou um grupo ou uma fração da coletividade. Ora, sòmente o conceito da lei concebida como regra geral constitui uma garantia contra a ação arbitrária da agência mais poderosa do Estado, pois nela, precìsamente, é que reside o poder, sôbre todos eminente e soberano, de criar o direito, de modificar as relações entre os indivíduos, de definir a propriedade e a liberdade, ou o resíduo de por que a Constituição, depois de determinar a parte de poder que compete, privilegiadamente, ao Estado, deixou aos indivíduos, para que pudesse haver na sociedade humana uma zona dominada por outros interêsses que não fôssem os da política, cuja alta tensão, se generalizada a todos os domínios, não deixaria ao homem outra perspectiva a não ser a do termiteiro, com a sua disciplina automática, ou da lei da jungle, em que cada um descreverá sôbre o domínio comum, na proporção da fôrça de que dispõe, a esfera do seu direito ou da sua liberdade.

Assim, é inevitável a conclusão de que o conceito da lei como sendo tão-sòmente o ato do Poder Legislativo que dispõe por via geral ou para um número indeterminado de casos, ou para todos os casos em que se realiza o estado de fato por ela tomado como base ou como critério para definir a compreensão ou a extensão dos seus preceitos, resulta do nosso sistema constitucional, particularmente por fôrça dos têrmos em que a Constituição declara os direitos ou as garantias individuais. Êsse, igualmente, não pode deixar de ser o conceito de lei nos regimes constitucionais filiados à mesma família, ao mesmo sistema, ou à mesma linhagem política, de que o nosso é apenas um dos mais recentes rebentos.

Já o velho Cooley, que talvez, e a enfatuação da moda, de cuja influência não estão imunes ainda os mais soberbos constitucionalistas, considera um tanto obsoleto, escrevia, há mais de 50 anos, estas palavras de tão aguda atualidade: "but every one has the right to demand that should be governed by general 
rules, and a special statute without his consent should be regulated by a different law from that which is applied to all similar cases, would not be legitimate legislation, but would be such an arbitrary mandate as ís not within the province of free government" (Cooley, "Constitutional Limitations", 7ª ed., pág. 559).

À Constituição de Weimar, assim como a todos os sistemas constitucionais do mesmo tipo, Carl Schimitt atribui, como necessário e fundamental, inerente à estrutura mesma da Constituição, o conceito de lei como proposição jurídica (Rechtssatz) geral ou abstrata, em cuja acepção se inclui o caso particular, não por enunciado direto, mas de maneira indireta, ou pela razão de pertencer à ordem de fatos ou de coisas pressuposta, pela própria lei, como condição para que se apliquem concretamente as suas disposições. Depois de se reportar, aprovando-a, à opinião de Duguit, segundo a qual apenas a norma geral, não porém uma medida individual (Einzelmassnahme), é lei no sentido próprio a êsse ato, não sòmente nos regimes propriamente constitucionais como no denominado "Estado de direito", e que uma lei que não disponha por via geral é "sans valeur juridique", Carl Schmitt, no parecer que emitiu sôbre o projeto de lei destinado a regular a liquidação dos bens pertencentes às antigas famílias reais da Alemanha, escreveu:

"Der Staat kannalles tun, aleernurdurch generalle Anordnung, also durch Gesetz, nicht durch individuelle Anweisungen. Tyran ist der, individuelle Entscheidungen ausserhalb der Gesetze trifft. Auf die grosse praktische Bedeutung dieser Theorie habe ich in einem Gutachten über die Befugnisse der Regierungskommission des Saargebietes hingewiesen" ("Unabhängigkeit der Richter, Gleichheit vor dem Gesetz und Gewährleistung des Privateigentums nach der Weimarer Verfassung", Berlim, 1926, pág. 22).

Em outra passagem do seu parecer, escreve Carl Schmitt:

"Corresponde, em verdade, à tradição liberal considerar o legislador vinculado à sua própria lei, de maneira a tornar-lhe impossível a sua violação por meio de exceções ou medidas individuais. Isto é conseqüência necessária do princípio da divisão dos poderes e da rigorosa distinção entre lei e aplicação da lei. À mais antiga tradição liberal se filia, igualmente, a idéia de que medidas individuais não são leis, como tais podendo apenas considerar-se as regras do direito, ou normas gerais, por oposição a medidas individuais" (ib., pág. 21).

E ainda: "Resume-se a lei em uma ordem individual (Einzelbefell)", "será uma simples medida, e não uma lei no sentido da regra fundamental, relativa à igualdade perante a lei" (ib., pág. 23). 
No mencionado parecer, Schmitt mostra, a tôda evidência, que o conceito de lei como regra ou proposição geral resulta, necessàriamente, da declaração dos direitos fundamentais, particularmente do princípio de igualdade perante a lei.

Carl Schmitt demonstra, ainda, de maneira absolutamente cabal, que o conceito de lei como regra geral ou abstrata resulta, igualmente, do princípio da independência da Justiça. Do só fato de ser o juiz, a um só tempo, independente e submetido à lei, decorre, de modo inevitável, que o juiz é independente no sentido de que não está sujeito a ordens, instruções ou avisos. Ora, assim sendo, a independência do juiz seria puramente ilusória, se da forma da lei pudesse revestir-se uma ordem individual. Desapareceria, igualmente, a distinção entre função legislativa e função jurisdicional, tornando-se desnecessária ou supérflua esta última função, se, mediante lei, o Parlamento pudesse dispor em relação a casos individuais ou concretos. Êle exerceria, nêsse caso, em tôda a sua plenitude, a função jurisdicional, destruído, integralmente, o princípio da independência do juiz, que passaria a ser mero instrumento das ordens ou das decisões que o legislador editasse sob a forma ou a aparência de lei (Carl Schmitt, op. cit., págs. 9 e 10).

E, logo em seguida, acrescenta Schmitt: “Eine gedankenlose Gleichstellung, die formalistisch behaupten wolltes Gesetz ist Gesetz (d. h. Gesetzgeber kann tun, was er will, es ist immer Gesetz, was er tut) würde denselben Absolutismus begründen wie der Satz: der Wille des Fürsten ist der Wille des Fürsten" (ib., pág. 11).

Posteriormente, no livro que publicou, em 1928, sôbre a "Teoria da Constituição" (Verfassungslehre), Carl Schmitt mostra, exaustivamente, como o conceito de lei como regra ou proposição geral resulta não sòmente do princípio da igualdade e do postulado da independência da Justiça, como, por igual ou com a mesma necessidade, do princípio da divisão dos poderes.

Assim, em relação à divisão dos poderes:

“Das System der sog. Teilung der Gewalten, d. h. der Unterscheidund von Gesetzgebung, Verwaltung und Justiz, ist nur so lange sinnovoll, a1s unter den Gesetz eine generelle Norm verstanden wird. Wenn bestimmte Staatliche Stel1en auf Grund verfassungssetzlicher Regelung dafür züständig, in einem besonderen Verfahren Gesetze zu erlasen, so ist dabei selbstverständlich ein Begriff des Gesetzes schon vorausgesetzt. Es wäre politisch ein Missbrauch und logisch eine Taschenspielerei, das Verhä1tnis umzukehren und einfach alles, was die für die Gesetzgebung zuständigen Stellen im Gesetzgebungsverfahren machen, als Gesetz (Gesetz im formellen Sinne) zu bezeichnen . 
Wenn durch Verfassungsgesetz bestimmt ist, wer Gesetze geben soll, so bedeut das offenbar nicht, dass diser Gesetzgeber das Verfahren der Gesetzgebung benutzen soll, um Prozesse zu entscheiden, oder Verwaltungsakte und Regierungshandlungen vorzunehmen. In einem Rechtsstaat soll das Gesetz herrschen und die gesamte Staatstätigkeit unter den Vorbehalt des Gesetzes stehen. Dadurch soll gerade verhindert werden, dass die für die Gesetzgebung zuständingen Instanzen an die Stelle der Herrschaft einer Norm ihre eigene Herrschaft setzen, indem sie beliebige Einzelbefehle, Massnahmen und Anweisungen von Gesetzen nicht mehr unterscheiden" (Carl Schmitt, "Verfassungslehre", pág. 151).

Sôbre a relação necessária entre o princípio da igualdade e o conceito de lei em sentido material, ou como norma que se caracteriza pela generalidade da sua compreensão e pela conseqüente indeterminação do seu endereço, Schmitt, embora reproduzindo as mesmas idéias do parecer anteriormente citado, insiste longa e luminosamente ("Verfassungslehre", págs. 154 e 155); demonstra, igualmente, que o princípio de liberdade pressupõe, com a mesma fôrça, aquêle conceito da lei ("Verfassungslehre", pág. 148); volta a referir-se à íntima conexão existente entre o conceito da lei e o princípio constitucional da independência do juiz ("Verfassungslehre”, págs. 155 e 156).

Finalmente, resume e condensa todo o pensamento anteriormente exposto, de maneira analítica e casuística, nesta síntese lapidar: "Alle diese Konstruktionen entfallen mit der Voraussetzung einer generellen Norm und zeigen, dass die Bindung der staatlichen Behörden an das Gesetz, das jede organisatorische Durchführung des Schutze der bürgerlichen Freiheit und jede einzelne bürgerlichrechtsstaatliche Forderung auf diesem Begriff des Gesetzes a1s einer generellen Norm beruhen.

Was den bürgerlichen Rechtsstaat vor völliger Auflösung in den Absolutismus wechselnder Parlamentsmeheiten bewahrt, ist nur der tatsächlich noch vorhandene Rest von Respekt vor diesem generellen Charahter des Gesetzes" (Carl Schmitt, "Verfassungslehre", pág. 156).

Walter Jellinek considera, igualmente, que a lei em sentido próprio é um preceito que o legislador dirige a uma pluralidade indeterminada de pessoas. Além dêsses preceitos, o legislador edita ordens que não contêm proposições jurídicas (Rechtssätze). À questão, porém, de se o legislador pode editar ordens destinadas a criar direitos ou deveres para pessoas determinadas, Jellinek responde negativamente, para o caso de um sistema constitucional, que adote manifestamente o princípio da separação dos poderes ("Verwaltungsrecht", 1929, página 9). 
No longo e minucioso exame crítico a que submeteu a teoria da lei proposta por Laband e Jellinek, Kelsen chega à conclusão de que lei é, tão-sòmente, o ato do Poder Legislativo que tem por conteúdo uma regra ou proposição jurídica. $\mathrm{O}$ ato do Poder Legislativo que não tem por conteúdo uma proposição jurídica (Rechtssatz) é "juridicamente irrelevante" ou "gleichsem eine hohle Nuss" (como uma noz vazia) (Kelsen, "Hauptprobleme der Staatsrechtslehre", págs. 537,566),

Hauriou estabelece, de modo expresso, a íntima relação que existe entre o princípio de igualdade e o conceito de lei como regra geral: "Au caractère fondamental de la loi d'être pour l'égalité, on peut rattacher cet autre caractère d'être une disposition par voie générale et, par consequent, une reglè juridique qui s'adresse forcément à plusieurs personnes et à plusieurs hypothèses" (Hauriou, "Droit Public", cap. XIII).

Sôbre as estreitas relações de dependência em que a liberdade, a igualdade, e as demais garantias contra a ação arbitrária do poder estão para o conceito de lei como disposição por via geral, ou como regra de direito, formulada mediante abstração do que é comum a um número indeterminado de casos, vejam-se as importantes considerações desenvolvidas por Leon Duguit, em seu "Traité de Droit Constitutionnel”, 2ª ed., volume II, §§ 15 e 16. Omissis. 